\title{
PANDEMI COVID-19 INDONESIA: KAJIAN PEMIKIRAN, KEBIJAKAN RITUAL IBADAH, DAN EKONOMI ISLAM (MAQASID ASY-SYARIAH)
}

\author{
Azibur Rahmana,1, Wahyu Eko Pujiantob,2, Indra Pratama Putra Salmonc,3, \\ ${ }^{a}$ Sekolah Tinggi Agama Islam Al-Akbar, Surabaya 60233, Indonesia \\ ${ }^{b}$ Universitas Nahdlatul Ulama Sidoarjo, Sidoarjo 61218, Indonesia \\ ${ }^{c}$ Universitas Bhayangkara Surabaya, Surabaya 60231, Indonesia \\ ${ }^{1}$ aziiburrahman@gmail.com*; ${ }^{2}$ wahyueko.mnj@unusida.ac.id *; ${ }^{3}$ indrapratama@ubhara.ac.id*,
}

ARTICLE INFO

Article history:

Received : 2021-06-24

Revised : 2021-07-27

Accepted : 2021-08-03

Keywords:

COVID-19

Islamic View

Islamic Economy

Kata kunci:

COVID-19

Pandangan Islam

Ekonomi Islam

\section{ABSTRACT}

Since Covid-19 pandemic occurred, the government and authorities in Indonesia have restricted almost all community activities in Indonesia, including various activities in houses of worship having an impact on the socio-economic vulnerability of Muslims. This study was to describe the phenomenon of the condition of Muslims affected by the pandemic, by providing a Muslim perspective as well as explaining how Islam responds to the epidemic phenomenon, restriction policies, and socioeconomics. This study applied a literature study with a qualitative approach to obtain descriptive and qualitative analytical data. The data were collected through reviewing literature and data about the current situation of Covid -19 pandemic and the ongoing dynamics of Muslim people. This study was a literature study collaborating between Islamic perspectives with contemporary phenomena and theories so that they contributed to strengthening the argument that Islam and its experiences were still very relevant to today's conditions. The result showed that: first, Islam provided jabariyah and qadariyah perspectives for Muslims in responding to the pandemic phenomenon; second, Islam provided relevant perspectives in policy formulation during the pandemic, and; third, Islam emphasized that Maqasid Asy-Sharia was a strategy and concept in overcoming the economic vulnerability of the community during and after the pandemic.

\section{ABSTRAK}

Sejak terjadi pandemi COVID-19 terjadi, pemerintah dan pihak otoritas di Indonesia membatasi hampir seluruh aktivitas masyarakat di Indonesia, termasuk berbagai aktivitas di rumah ibadah yang berdampak pada kerentanan sosial ekonomi umat muslim. Kajian ini bertujuan untuk menjabarkan fenomena kondisi umat muslim terdampak pandemi, dengan memberikan cara pandang muslim sekaligus memaparkan bagaimana Islam menyikapi fenomena wabah, kebijakan pembatasan, dan sosial ekonomi. Penelitian ini menggunakan metode penelitian studi kepustakaan dengan pendekatan kualitatif untuk memperoleh data deskriptif dan kualitatif analitis. Metode pengumpulan data yakni dengan kajian kepustakaan, literatur, dan data mengenai situasi terkini pandemi COVID-19 dan dinamika masyarakat masyarakat muslim yang tengah berjalan. Kajian ini merupakan studi literatur yang mengkolaborasikan antara perspektif Islam dengan fenomena dan teori kontemporer sehingga berkontribusi dalam memperkuat argumen bahwa Islam beserta pengalaman yang dimiliki masih

\footnotetext{
DOI: $10.23971 /$ jsam.v\%vi\%i.2983
}

W : http://e-journal.iain-palangkaraya.ac.id/index.php/jsam

E : Jsam.iainpky@gmail.com 
sangat relevan dengan kondisi hari ini. Hasil penelitian menunjukkan bahwa: pertama, Islam memberikan perspektif jabariyah dan qadariyah bagi umat muslim dalam menyikapi fenomena pandemi; kedua, Islam memberikan cara pandang yang relevan dalam rumusan kebijakan selama pandemi, dan; ketiga, Islam menegaskan bahwa Maqasid Asy-Syariah sebagai strategi dan konsep dalam mengatasi kerentanan ekonomi masyarakat selama dan pasca pandemi.

\section{Pendahuluan}

Hingga hari ini, belum ada ahli yang secara akurat menyatakan secara pasti kapan berakhirnya pandemi COVID-19 di dunia. Berbagai studi sebelumnya menyebutkan pandemi tersebut berawal dari China dengan gejala berupa gangguan pernafasan hingga kematian dan pertama kali muncul pada tahun 1960 (Al-Osail \& Al-Wazzah, 2017; Q. Li, Feng, \& Quan, 2020; R. Li, Qiao, \& Zhang, 2020). Kondisi semakin parah ketika belum ada vaksin yang secara pasti mampu menyembuhkan gejala COVID-19 tersebut (Whitworth, 2020). Serangan terhadap mortalitas dan morbiditas manusia berlangsung sangat cepat, dan dalam hitungan minggu persebaran virus telah berdampak pada 100 hingga 150 negara (Biswas, Khaleque, \& Sen, 2020; Remuzzi \& Remuzzi, 2020; Vankadari \& Wilce, 2020). Pemerintah, stakeholder, dan berbagai praktisi ahli kesehatan telah melakukan berbagai upaya penanganan mulai yang bersifat medis hingga non-medis agar dapat mencegah penularan dan memutus rantai persebaran melalui kebijakan, strategi, dan program khusus namun kenyataan terjadi di luar harapan. Kondisi hari ini menunjukkan bahwa saat ini pandemi masih terus berlangsung hingga upaya terakhir yang muncul adalah upaya merumuskan strategi alternatif untuk mencegah pandemi terjadi secara berkelanjutan.

Pandemi wabah COVID-19 hari ini telah berdampak signifikan pada hampir seluruh aspek kehidupan dan memberikan perubahan, termasuk dalam aktivitas keagamaan umat muslim di dunia. Dampak ini juga berlaku bagi ritual masyarakat muslim di dunia dalam proses peribadatan. Di masjid terbesar dunia, di Kota Mekah, Arab Saudi, pihak otoritas memberlakukan larangan untuk melakukan peribadatan sebagai upaya mencegah penyebarluasan wabah. Otoritas mengganti tata cara peribadatan melalui siaran langsung internet dalam menyiarkan doa dan khotbah (Ibrahim, 2020). Selain itu juga terjadi peniadaan ibadah haji pada tahun 2020 dan penundaan ibadah umrah hingga batas waktu yang tidak ditentukan.

Bagi masyarakat muslim yang terbiasa melaksanakan ritual peribadatan di rumah ibadah, pandemi COVID-19 telah berperan mengubah ritual peribadatan yang biasa mereka jalankan. Ritual seperti salat wajib berjamaah, salat jumat, kajian keagamaan, hari raya keagamaan, dan ibadah lainnya yang umumnya bersifat kolektif, berubah menjadi individu dan berlangsung di kelompok yang jauh lebih kecil. Hal tersebut bukan hanya karena pandemi COVID-19, tapi juga karena adanya anjuran dari pemerintah dan pihak otoritas untuk melakukan ibadah di rumah masing-masing. Meskipun di beberapa lapisan masyarakat masih terdapat aktivitas peribadatan secara kolektif berjamaah, namun adanya perubahan tersebut telah terjadi hari ini dan berpotensi berlangsung hingga masa yang akan datang (Bentzen, 2021).

Di Indonesia, pandemi COVID-19 juga turut memberikan dampak pada aktivitas ibadah berjamaah dan beberapa kegiatan keagamaan lain. Terhitung sejak bulan Maret 2020 sejak pihak otoritas menyatakan bahwa pandemi COVID-19 sebagai bencana nasional, pembatasan di rumah-rumah ibadah berlangsung dengan dikoordinir secara terpusat melalui Kementerian Agama Republik Indonesia. Muncul pro dan kontra dalam kaitannya dengan pembatasan tersebut. Salah satu protes terkuat adalah pendapat yang menyatakan bahwa rumah ibadah tertutup dan sangat dibatasi, tetapi 
masih banyak pusat-pusat keramaian yang terbuka untuk umum selain rumah ibadah yang dibuka seperti pasar, mall, dan kawasan lainnya. Dan juga, pemerintah di Indonesia yang merupakan pihak otoritas terkesan tidak memiliki komitmen dan tidak konsisten dalam pemberlakuan karantina masyarakat di tempat-tempat umum.

Ibadah berjamaah di Indonesia selain sebagai bentuk kewajiban utama masyarakat muslim, juga merupakan kebiasaan sosial yang telah berlangsung lama dan turun temurun. Kebiasaan tersebut melambangkan solidaritas masyarakat muslim dan kebiasaan bersosialisasi masyarakat yang didasari oleh kuatnya rasa persatuan dan kesatuan terlepas dari adanya heterogenitas warga negara. Dari aspek kebangsaan, semboyan "Bhineka Tunggal Ika" atau memiliki arti "unity in diversity" secara tidak langsung termanifestasi dalam kehidupan keagamaan umat muslim ketika melakukan ritual keagaaman di rumah-rumah ibadah. Letak heterogenitas umat muslim yakni pada keberagaman suku, asal daerah, warna kulit, dan latar belakang lainnya yang kemudian menyatu dalam satu rumah ibadah.

\section{Tinjauan Pustaka}

Masyarakat muslim di Indonesia yang terdiri dari beragam stratifikasi baik secara sosial maupun ekonomi, semua aspek tersebut tidak menjadi tolok ukur kuatnya keyakinan ketika melangsungkan ibadah berjamaah. Pada periode sebelum pandemi COVID-19 terjadi, rumah ibadah sejatinya telah menjadi sarana yang mendorong adanya kesetaraan umat muslim di Indonesia dan meningkatkan solidaritas sosial. Kesetaraan tersebut hari ini justru menjadi tempat terbatas bagi umat muslim di Indonesia yang kemudian berpotensi memunculkan kembali adanya model stratifikasi sosial ekonomi yang muncul di masa lalu. Padahal, rumah ibadah umat muslim di Indonesia tengah menerapkan paradigma baru berupa rumah ibadah sebagai sarana mengharmoniskan kondisi sosial ekonomi umat muslim di Indonesia. Sebagaimana kajian terdahulu dari (Iqbal \& Mirakhor, 2010; Sadeq, 1990; Salleh, 2017) yang mencoba memberikan konsep alokasi sumber daya sosial ekonomi melalui rumah ibadah umat muslim. Mereka mencoba memberikan konsep antara lain: dari sisi sosial, terjadi kontribusi silang berbentuk zakat, infaq, dan sedekah antara umat muslim kaya dengan umat yang miskin secara sukarela, dan; dari segi ekonomi, terjadi aktivitas ekonomi berupa jual beli di lingkungan sekitar rumah ibadah. Kedua hal tersebut merupakan satu bentuk potensi yang terjadi di lingkungan peribadatan umat muslim yang mana bagi yang memiliki kesehatan jasmani dan berkesempatan, maka mereka mampu berperan dalam aktivitas ekonomi umat. Sementara bagi yang umat tidak mampu, maka mereka mendapatkan zakat, infaq, atau sedekah, yang mana hal tersebut setara dengan konsep social economic security insurance.

Terdapat 2 kutub besar yang saling berlawanan dalam konteks keyakinan masyarakat beragama. Dalam hal ini kami mengkhususkan pada agama Islam. Kutub Pertama, adalah beberapa filsuf pernah menyatakan bahwa agama di era modern akan berangsur-angsur padam (Durkheim, 2013; Freud \& Gay, 1989; Marx, 1970; Weber, 2010), yang mana hal tersebut turut berdampak pada kondisi sosial ekonomi masyarakat. Tetapi meskipun agama belum padam sepenuhnya (Iannaccone, 1998; Norris \& Inglehart, 2011; Stark \& Finke, 2000), kondisi hari ini menampakkan gejala redupnya agama sedikit demi sedikit melalui pandemi COVID-19. Kutub Kedua, sebaliknya, bahwa Islam terus memperkuat diri sebagai agama yang mampu beradaptasi di segala peradaban melalui berbagai pemikiran, baik secara murni atau praksis. Studi yang dilakukan (Mugiyono, 2013) menunjukkan bahwa terdapat beberapa faktor yang mempengaruhi kemampuan adaptabilitas yakni: Pertama, sejarah menunjukkan bahwa dari era klasik hingga modern, Islam menerapkan keterbukaan, toleran, kebebasan berpikir, dan akomodatif terhadap berbagai pemikiran baru; Kedua, pemikiran Islam melingkupi seluruh bidang pemikiran dan aplikasi kehidupan nyata; Ketiga, dukungan kelembagaan menjadi salah satu tumpuan perkembangan pemikiran Islam, dan; Keempat, perkembangan pemikiran dan peradaban Islam berfokus pada dampak positif kondisi umat Islam di 
Dunia. Berdasar pada kedua kutub yang saling berlawasan tersebut, maka kemudian muncul pertanyaan bagaimana seharusnya Islam memberikan cara pandang yang ideal terhadap fenomena pandemi hari ini, baik secara filosofis maupun secara otoritas representasi dari pemeluk agama Islam di Indonesia. Di sisi lain peran rumah ibadah mulai terbatas, muncul pertanyaan lain berupa bagaimana peran Islam dalam menjaga keberlangsungan hidup umat muslim dan menjaga solidaritas sosial ekonomi di tengah krisis sosial ekonomi umat selama pandemi berlangsung.

\section{Metodologi Penelitian}

Kajian ini menggunakan metode pendekatan kajian literatur kualitatif dan mengeksplorasi bagaimana muslim secara akademik memberikan cara pandang baik secara pemikiran maupun sikap yang harus diambil dalam menangani kondisi sosial ekonomi terdampak selama Covid-19 melanda. Kami menggunakan metode tersebut dengan tujuan menghasilkan analisis mendalam yang berfokus pada fenomena tertentu (Creswell \& Creswell, 2018). Kami menggunakan beberapa bahan terbaru yang berfokus pada perkembangan kondisi umat muslim di dunia dan Indonesia, kajian terdahulu tentang topik bahasan, dan rujukan pemikiran Islam dalam mengangani situasi wabah. Kami juga melakukan analisis dan triangulasi dengan fokus menghasilkan: a) validitas dan reliabilitas literatur dan data; $b$ ) temuan gap dalam kajian; c) merumuskan hasil secara tematik, dan; d) temuan fenomena sehingga kajian yang berlangsung memiliki implikasi teoretis dan praktis.

\section{Hasil dan Diskusi}

\section{Rasionalitas Pemikiran Islam dalam COVID-19: Qodariyah dan Jabariyah}

Melalui Islam, kami melihat dua perspektif dalam menelaah fenomena pandemi COVID-19 hari ini. Perspektif pertama adalah cara pandang Qadariyah, dan; kedua, berupa cara pandang Jabariyah. Masing-masing cara pandang memiliki pola tertentu dalam mendefinisikan masalah dan memetakan solusi penyelesaian melalui pola pemikiran. Dalam cara pandang logika, perspektif Qadariyah adalah paham yang relevan dengan penggunaan kehendak manusia yang kemudian didukung dengan keberadaan nalar logis dan rasionalitas, sehingga setiap fenomena dan kejadian merupakan hasil dominasi campur tangan manusia dan manusia itu pula yang mampu mengatasi. Dalam gaya pemikiran barat, pola pemikiran ini sangat dekat dengan penggunaan logika sebagai dasar mengkaji satu fenomena dan kebebasan berpikir untuk mencari jalan keluar permasalahan. Kebebasan berbeda dengan pola pikir kebebasan tanpa batas, melainkan kebebasan dalam konteks berpikir indetermenisme. Peran Isam dalam konteks berpikir indetermenisme sendiri melalui keberadaan lingkungan dan prinsip keterbukaan yang selaras dengan pola kebebasan berpikir. Di samping itu, Islam juga mendorong agar umat muslim memiliki motivasi berusaha menyelesaikan permasalahan dan tantangan peradaban dalam bentuk ikhtiar pada aspekaspek spiritual, termasuk ilmu pengetahuan, pengalaman, dan keterampilan.

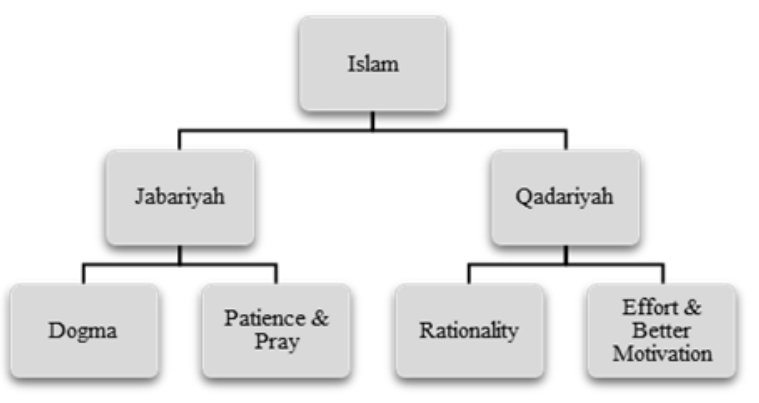

Gambar 1. Model Cara Pandang Islam Terhadap Fenomena

Dalam perspektif pemikiran lainnya, Islam juga memiliki perspektif Jabariyah yang merupakan sisi lain dari Qadariyah. Perspektif ini merupakan bentuk cara pandang dogmatis dalam Islam, atau dalam cara pandang sains, perspektif pemikiran ini relevan dengan gaya pikir determinisme. Dalam praktiknya, cara pandang ini secara penuh menyuarakan bahwa semua fenomena yang ada di bumi adalah murni keputusan Tuhan. Sebagai konsekuensi, maka umat muslim hanya berhak menerima dan memiliki kewajiban untuk patuh pada ketentuan dan keputusan Tuhan. Secara istilah Islam, cara pandang tersebut dikenal dengan istilah "kasb" yang secara literal memiliki arti usaha. Namun berbeda dengan usaha yang ada pada cara pandang Qadariyah, "kasb" dalam pemikiran 
Jabariyah bermakna bahwa semua aktivitas manusia adalah kehendak Tuhan sepenuhnya, yang mana manusia tidak memiliki kemampuan mengendalikan secara penuh. Dengan adanya makna tersebut, maka kami memahami bahwa perspektif Jabariyah meletakkan rasionalitas kebebasan berpikir dan melakukan tindakan berada pada strata yang rendah karena semua fenomena yang terjadi merupakan kehendak penuh dari Tuhan. Jika umat muslim secara penuh menggunakan gaya pemikiran Jabariyah, maka yang terjadi adalah pemikiran dalam segala aspek kehidupan tidak akan berkembang, bahkan terhenti karena hanya terikat oleh dogma.

Berangkat dari kerangka pemikiran sebelumnya, kami mengemukakan suatu argumen bahwa hingga hari ini, 2 cara pandang Islam masih relevan dalam kehidupan umat muslim. Alasan kuat kami adalah: pertama, cara pandang Jabariyah berupa takdir yang pasti terjadi dan merupakan kehendak Tuhan, dan; kedua, cara pandang Qadariyah yang menjadikan umat muslim berhak berpikir dan melakukan ikhtiar sebagaimana tujuan Tuhan memberikan akal pikiran untuk manusia adalah untuk berpikir, berkembang, dan bermanfaat bagi lingkungan. Dalam konteks pandemi COVID-19, fenomena yang telah terjadi meliputi 2 sisi yang harus diterjemahkan dalam cara pandang Jabariah dan Qadariyah. Cara pandang Jabariyah yang harus dipahami adalah pandemi wabah hari ini adalah takdir dan muncul pemahaman bahwa pandemi ini telah membawa perubahan negatif bagi aktivitas peribadatan umat muslim. Melalui cara pandang Jabariyah, wabah yang terjadi hari ini pernah terjadi di masa lampau. Dalam Al-Qur'an, secara eksplisit kami mengutip dari Surat alBaqarah (2) ayat 155-157:

“...Dan Kami pasti akan menguji kamu dengan sedikit ketakutan, kelaparan, kekurangan harta, jiwa, dan buah-buahan. Dan sampaikanlah kabar gembira kepada orang-orang yang sabar..." (2:155)

“...(yaitu) orang-orang yang apabila ditimpa musibah, mereka berkata "Inna lillahi wa inna ilaihi raji'un" (sesungguhnya kami milik Allah dan kepada-Nyalah kami kembali)..." (2:156)
“...Mereka itulah yang memperoleh ampunan dan rahmat dari Tuhannya, dan mereka itulah orang-orang yang mendapat..." (2:157)

Secara Jabariyah, maka kondisi hari ini menunjukkan bahwa fenomena pandemi wabah COVID-19 merupakan kehendak Tuhan. Konteksnya adalah memberikan bentuk ujian pada manusia dengan ketakutan dan kepanikan, lalu di bagian akhir apakah manusia menunjukkan perubahan yang lebih baik atau justru sebaliknya. Merujuk Surat alBaqarah (2) ayat 155-157 tersebut, maka Islam memahami bahwa pandemi COVID-19 yang terjadi saat ini secara penuh menjadi kuasa Tuhan dan manusia hanya berhak menerima kondisi pandemi yang terjadi. Berdasarkan tinjauan retrospektif, masyarakat muslim meyakini pandemi COVID-19 merupakan takdir yang mereka anggap sebagai bentuk ujian di luar kemampuan mayoritas masyarakat muslim. Ujian tersebut menimbulkan adanya fenomena kepanikan, ketakutan, dan kekhawatiran terhadap wabah yang sedang melanda. Kepasrahan juga terjadi yang kemudian meyakini bahwa virus COVID-19 merupakan salah satu mahluk ciptaan Tuhan dan hidup atas kehendak Tuhan, yang kemudian tunduk pada kehendak Tuhan. Dengan adanya keyakinan demikian, maka masyarakat muslim melakukan kepasrahan, kesabaran, dan mengembalikan semua keputusan hidup pada kuasa Tuhan melalui doa.

Manifestasi lain adalah melihat secara prospektif, yang mana keduanya adalah fenomena sebab akibat. Manifestasi ini juga merupakan aliran pemikiran dengan cara pandang Qadariyah atau determenisme. Sebagai bentuk akibat, masyarakat muslim menggunakan sudut pandang tersebut dengan berusaha mempedomani diri melalui literatur dan sejarah Islam di masa lampau. Sejarah dalam konteks ini merupakan pengalaman pemimpin muslim terdahulu dan kepala negara yakni Nabi Muhammad yang saat ini menjadi salah satu rujukan umat muslim di dunia dalam menangani wabah di era modern. Sudut pandang tersebut termanifestasikan dalam bentuk ikhtiar atau upaya mencegah dan menanggulangi ancaman persebaran dan memutus rantai 
persebaran virus. Pengalaman dari masyarakat muslim terdahulu adalah dengan mengikuti keputusan dan kebijakan pemimpin ketika terjadi wabah. Riwayat yang menjelaskan kebijakan pemimpin dalam menyikapi wabah dan sikap umat muslim pada masa lampau adalah:

“...Jika kalian mendengar tentang wabah-wabah di suatu negeri, maka janganlah kalian memasukinya. Tetapi jika terjadi wabah di suatu tempat kalian berada, maka janganlah kalian meninggalkan tempat itu..." (HR Al-Bukhari \& Muslim)

Sebagai pemimpin, kepala negara memiliki otoritas untuk melindungi masyarakat termasuk dari kerentanan wabah penyakit, yang mana pada konteks Islam tersebut adalah pes dan lepra. Sikap tersebut berupa keputusan larangan untuk memasuki satu wilayah atau meninggalkan wilayah yang sedang terjangkit wabah. Kondisi ini menunjukan bahwa di masa lampau telah ada upaya untuk melakukan karantina ketika wabah terjadi melalui pemimpin negara dalam tindak pencegahan wabah. Pencegahan tersebut baik berbentuk menghindarkan masyarakat dari terjangkitnya wabah atau menjalarnya wabah ke negara-negara lain. Di era modern hari ini, kebijakan teknis dalam mengatasi wabah secara implisit tampak sejalan dengan pengalaman masyarakat muslim terdahulu yakni melalui anjuran untuk tidak bepergian dan karantina wilayah yang masih relevan. Secara rasional, karantina tersebut adalah bentuk pengambilan kebijakan yang berorientasi pada upaya pencegahan persebaran/penularan dan pemulihan bagi masyarakat terdampak COVID-19 serta upaya tanggap terhadap bencana (Qi, Du, Liu, Zhao, \& Dong, 2020; Rheinberger \& Treich, 2017).

Pandemi COVID-19 sejatinya telah membawa dampak kerentanan bagi semua pihak, termasuk mayoritas masyarakat muslim yang mengalami perubahan signifikan dalam berbagai aktivitas. Untuk mencegah adanya dampak yang lebih buruk, maka upaya yang dilakukan selain menerima takdir (jabariyah), adalah dengan melakukan ikhtiar untuk keberlanjutan umat muslim (qadariyah). Ikhtiar tersebut berbentuk menjaga diri dan jiwa untuk keberlanjutan hidup individu, serta menjaga sendi-sendi sosial ekonomi umat dalam rangka keberlanjutan kehidupan umat muslim di Indonesia. Keduanya merupakan aspek yang dilandasi pedoman kehidupan kemanusiaan dan bernegara. Dalam upaya ikhtiar menjaga diri secara individu, upaya dilandaskan pada Fatwa MUI Nomor 14 Tahun 2020 tentang Penyelenggaraan Ibadah dalam Situasi Terjadi Wabah Covid-19. Kondisi ini mengingat tingkat kerawanan dan ancaman yang mungkin terjadi ketika dilaksanakan ibadah secara berjamaah bagimasing-masing individu. Selain itu, menjaga sendi-sendi sosial ekonomi umat dalam rangka keberlanjutan kehidupan umat muslim Indonesia juga memiliki peran yang penting dalam mempererat kekuatan sesama muslim. Hal ini juga diperkuat melalui Fatwa MUI Nomor 23 Tahun 2020 tentang Pemanfaatan Harta Zakat, Infaq, dan Shadaqah untuk Penanggulangan Wabah Covid-19 dan Dampaknya. Fatwa tersebut mempetimbangkan bahwa pandemi hari ini bukan hanya berkaitan dengan urusan kesehatan, melainkan kerentanan pada aspek sosial ekonomi umat muslim yang mana secara keseluruhan harus dilakukan bentuk penerimaan secara ikhlas, namun juga disertai dengan ikhtiar sebagai wujud kekuatan masyarakat muslim menghadapi ujian kehidupan.

\section{Fatwa Majelis Ulama Indonesia (MUI) Ritual Ibadah Berjamaah dan Dukungan Sosial Ekonomi Umat}

Agama Islam menerapkan syariat bahwa terdapat keutamaan ketika umat muslim melakukan ritual ibadah berjamaah seperti melakukan salat fardhu di masjid dan salat Jumat. Keduanya memiliki tingkat keutamaan nilai yang lebih tinggi dibandingkan dengan ibadah secara individu. Situasi pandemi COVID-19 hari ini menjadikan adanya kondisi yang berbeda dengan harapan umat muslim sebagaimana yang dianjurkan dalam agama. Majelis Ulama Indonesia (MUI) Pusat pada bulan Maret 2020 telah menerbitkan Fatwa Nomor 14 Tahun 2020 tentang Penyelenggaraan Ibadah dalam Situasi Terjadi Wabah Covid19. Substansi dari fatwa tersebut adalah upaya menjaga kesehatan dan menjauhi kawasan potensial untuk penularan wabah COVID-19. Pembatasan di rumah ibadah, social/physical distancing, dan implementasi 
protokol kesehatan di beberapa aktivitas keagamaan merupakan bentuk anjuran dari otoritas MUI. Selain pertimbangan medis umat beragama di Indonesia secara umum, dasar dari kebijakan tersebut adalah pertimbangan secara filosofis dalam berkeyakinan khusus bagi umat muslim (Aji \& Habibaty, 2020).

“...Hai orang-orang beriman, apabila diseru untuk menunaikan salat Jum'at, maka bersegeralah kamu kepada mengingat Allâh dan tinggalkanlah jual beli, yang demikian itu lebih baik bagimu jika kamu mengetahui..." (62:9)

“... Jum'at (Salat Jumat) itu wajib bagi setiap muslim dengan berjamaah kecuali empat (golongan), yaitu: hamba sahaya, wanita, anak-anak, dan orang yang sakit..." (HR Abu Dawud:1069)

"Hendaklah orang yang suka meninggalkan salat Jum'at menghentikan perbuatan mereka, atau benar-benar Allâh akan menutup hati mereka, kemudian mereka benar-benar menjadi termasuk orang-orang yang lalai..."

Bagi masyarakat muslim di Indonesia, pandemi wabah hari ini memunculkan dilema dalam prosesi ritual keagamaan. Salah satu contoh adalah pada saat ritual salat berjamaah di rumah ibadah yang merupakan kewajiban seorang muslim. Kebijakan tersebut memberikan pembatasan rumah ibadah melalui fatwa otoritas keagamaan. Di sisi lain, terjadi praktik yang berlainan, bahwa syariat yang meniscayakan keterlibatan orang banyak misalnya salat berjamaah dan salat Jum'at di masjid karena merupakan kewajiban mendasar masyarakat muslim dan pihak otoritas juga memperbolehkan dengan disetai protokol kesehatan. Tetapi pada dasarnya keduanya memiliki keutamaan ketika dilakukan secara berjamaah dan memiliki konsekuensi yang tinggi dalam religiusitas umat muslim.

“...dan dirikanlah salat, tunaikanlah zakat, dan ruku'lah bersama orang-orang yang ruku..." (2:43)

“...Barangsiapa yang ingin ketika berjumpa dengan Allah esok dalam keadaan sebagai seorang Muslim, maka hendaknya dia menjaga shalat 5 waktu di tempat dikumandangkan adzan (yaitu di masjid).
Karena Allah telah mensyariatkan kepada Nabi kalian jalan-jalan petunjuk. Dan shalat 5 waktu di masjid adalah salah satu di antara jalan-jalan petunjuk. Seandainya kalian shalat di rumah-rumah kalian sebagaimana orang yang tidak ikut shalat berjamaah ini, ia shalat di rumahnya, maka sungguh kalian telah meninggalkan sunnah Nabi kalian. Dan jika kalian meninggalkan sunnah Nabi kalian, maka sungguh kalian akan tersesat. Dan sungguh aku melihat dahulu kami para sahabat, tidak ada yang meninggalkan shalat berjamaah di masjid kecuali orang munafik yang jelas kemunafikannya. Dan sungguh dahulu ada sahabat yang dibopong ke masjid dan ditopang di antara dua lelaki agar bisa berdiri untuk shalat di shaf..." (HR Muslim:654)

“...Kami pernah safar bersama Rasulullah Shallallahu'alaihi Wasallam, lalu turunlah hujan. Beliau besabda: 'bagi kalian yang ingin shalat di rumah dipersilakan..." (HR. Muslim: 698)

Selain salat Jumat, salat berjamaah juga merupakan bentuk kewajiban seorang muslim. Meskipun terdapat kelonggaran dan umat muslim dapat mendapat keringanan dalam bentuk melaksanakan secara individu, namun pada dasarnya salat berjamaah dan salat Jumat memiliki derajat kesucian yang tinggi dalam Islam. Terdapat sanksi agama secara tegas ketika seorang muslim tidak melaksanakan salat berjamaah, tetapi juga terdapat pengecualian ketika terjadi hal-hal di luar kendali manusia. Dalam kondisi berhadapan dengan sanksi yang tegas dan dihadapkan dengan pola pikir jabariyah, maka menjadi dilema ketika berkaitan dengan konteks terjadinya pandemi wabah COVID-19. Dilema terebut apakah harus mengikuti salat berjamaah (dengan menerapkan protokol kesehatan) atau meninggalkan salat berjamaah (dengan alasan menghindari wabah COVID-19). Dua kondisi tersebut yang hari ini menjadi pertanyaan besar bagi umat muslim di Indonesia dan menunjukkan bahwa tindak pemutusan penyebaran wabah COVID-19 tidak kunjung stabil.

“...Dia-lah (Tuhan) yang menghidupkan dan mematikan, Dia (Tuhan) juga yang mengatur 
pergantian malam dan siang. Tidakkah menalarnya?..." (23:80)

“...Katakanlah: samakah antara orang yang buta dengan orang yang melihat?! Tidakkah kalian memikirkannya?!..." (6:50)

“...Perhatikanlah, bagaimana kami menjelaskan berulang-ulang tanda-tanda kekuasaan Kami, agar meeka memahaminya..." (6:65)

Fatwa MUI yang merupakan kebijakan sejatinya merupakan keputusan yang dilatarbelakangi oleh upaya menjaga kondisi peribadatan umat muslim di Indonesia. Fatwa yang berisi kewajiban menjaga kesehatan diri secara umum hingga kondisi aktivitas selama melakukan peribadatan adalah pilihan rasional dalam konteks mempertahankan kesehatan umat muslim. Umat muslim juga sangat tidak dianjurkan hanya berpasrah dan merasa bahwa semua kehendak Tuhan, tetapi juga harus menggunakan rasionalitas dan dalam melakukan ritual keagamaan.

“...Setiap orang wajib melakukan ikhtiar menjaga kesehatan dan menjauhi setiap hal yang diyakini dapat menyebabkannya terpapar penyakit, karena hal itu merupakan bagian dari menjaga tujuan pokok beragama (al-Dharuriyat al-Khams)..." (Fatwa MUI Nomor 12/2020)

“...Orang yang telah terpapar virus Corona, wajib menjaga dan mengisolasi diri agar tidak terjadi penularan kepada orang lain. Baginya shalat Jumat dapat diganti dengan shalat zuhur di tempat kediaman, karena shalat jumat merupakan ibadah wajib yang melibatkan banyak orang sehingga berpeluang terjadinya penularan virus secara massal. Baginya haram melakukan aktifitas ibadah sunnah yang membuka peluang terjadinya penularan, seperti jamaah shalat lima waktu/ rawatib, shalat Tarawih dan Ied di masjid atau tempat umum lainnya, serta menghadiri pengajian uтит dan tabligh akbar..."(Fatwa MUI Nomor 12/2020)

Fatwa MUI yang merupakan rumusan kebijakan bagi aktivitas umat beragama mendasarkan pada kondisi kontekstual pandemi hari ini. Salah satu poin mendasar dalam ritual ibadah yakni ketika melakukan salat berjamaah dan salat Jumat di rumah ibadah. Sebelumnya dijelaskan bahwa kondisi pandemi hari ini menjadikan umat muslim merasakan dilema. Ketika umat muslim tidak melakukan ritual ibadah berjamaah maka akan mendapatkan sanksi secara agama, tetapi ketika mengikuti ritual ibadah berjamaah akan berpotensi terkena dampak penularan virus COVID-19. Keduanya ketika dilakukan maka terdapat Pada dasarnya, Islam sendiri menerapkan pertimbangan bahwa pada konteks ritual peribadatan, umat muslim harus mengukur tingkat manfaat dengan mudharat (kerugian). Artinya bahwa terdapat pemikiran yang rasional dengan mengedepankan akal pikiran dan menjaga jiwa dalam beribadah yang notabene merupakan dogma dan ketentuan dari Tuhan.

“...Dahulu Nabi (Muhammad) memerintahkan muadzin beradzan lalu di akhirnya ditambahkan lafadz 'shalluu fii rihaalikum' (salatlah di rumah-rumah kalian) ketika malam sangat dingin atau hujan dalam safar..." (HR Bukhari:616; HR Muslim:699)

“...Kami pernah safar bersama Rasulullah Shallallahu'alaihi Wassalam, lalu turunlah hujan. Beliau bersabda: 'bagi kalian yang ingin shalat di rumah dipersilakan'..." (HR. Muslim: 698)

MUI sebagai pihak otoritas telah menunjukkan rasionalitasnya karena mengambil substansi anjuran pelarangan ibadah di rumah ibadah dan sejalan dengan anjuran agama Islam. Konteks kasus dahulu mengambil contoh dalam bentuk "musim hujan", yang mana hal tersebut merupakan halangan bagi banyak umat muslim untuk melakukan ritual salat berjamaah. Hari ini, konteks halangan tersebut sejalan dengan adanya potensi penularan wabah yang bukan hanya umat muslim alami, tetapi masyarakat di Indonesia dan dunia secara keseluruhan. Selain itu, kasus terdampak COVID-19 di Indonesia menunjukkan bahwa masyarakat terdampak masih cenderung terus meningkat mulai dari bulan Maret 2020 hingga saat ini.

Rasionalisasi kebijakan yang dikeluarkan oleh MUI mendasarkan pada kondisi bagaimana pengalaman umat muslim terdahulu beribadah ketika terjadi wabah. 
Sebagai bentuk afirmasi teoritis, maka rasionalitas tersebut sejalan dengan adanya informasi tentang masalah, faktor penyebab, serta alternatif jalan keluar (Birkland, 2010). Artinya keputusan tersebut menjadi pilihan strategi yang baik untuk pengambil keputusan dalam merumuskan kebijakan dan mengambil keputusan sehingga mampu membantu menyelesaikan kompleksitas masalah sosial di masyarakat modern (Dror, 1964; Ferris, 2011). Dampak buruk pandemi COVID-19 yang menjangkiti masyarakat hingga kini terus berlanjut. Bukan hanya aspek kesehatan yang terkena dampak, tapi juga kondisi kerentanan sosial ekonomi akibat pandemi wabah yang sudah terjadi sjak awal 2020. Pemerintah sebagai agen tunggal memiliki konsekuensi selama membuat kebijakan dan keputusan terbaik dalam mengatasi wabah tersebut. Artinya bahwa dari segi perencanaan, pelaksanaan, hingga evaluasi harus melalui metode, menghasilkan alternatif terbaik, dan rasional. Rasional dalam hal ini menjadi kata kunci yang berdasarkan asumsi berupa pengambil keputusan mempunyai hampir semua informasi tentang masalah, faktor penyebab, serta alternatif jalan keluar yang berbeda dengan pendekatan inkrementalisme atau bounded rationality (Anderson, 2005; Birkland, 2010). Hal ini sekaligus melengkapi bagaimana memberikan pemahaman terhadap upaya penyusunan kebijakan rasional penanganan pandemi Covid-19 mengingat konsekuensi (secara umum) bencana erat kaitannya dengan kebijakan selanjutnya atau dampak kesejahteraan seperti berkurangnya konsumsi dan krisis keuangan (Arrow \& Priebsch, 2014; Martin \& Pindyck, 2015, 2021).

\section{Perspektif Maqasid Asy-Syariah dalam Mengatasi Kerentanan Sosial Ekonomi}

MUI telah menerbitkan Fatwa Nomor 23 Tahun 2020 tentang Pemanfaatan Harta Zakat, Infaq, dan Shadaqah untuk Penanggulangan Wabah Covid-19 dan Dampaknya. Penerbitan Fatwa tersebut tentunya telah mempertimbangkan dan mengindikasikan permasalahan yang dihadapi oleh masyarakat muslim di Indonesia. Indikasi khusus tersebut berupa adanya dampak negatif pandemi terhadap sendi-sendi sosial ekonomi $87 \%$ umat muslim di Indonesia, dalam rangka keberlanjutan kehidupan. Fatwa tersebut menganjurkan secara kuat bagi masyarakat muslim dengan daya dukung sosial ekonomi kuat untuk mensegerakan adanya pemberian bantuan sosial dan ekonomi bagi masyarakat muslim yang tengah mengalami kerentanan atas pandemi. Upaya tersebut merupakan penjabaran dari rasionalitas qadariyah yang berbentuk ikhtiar menjaga harta secara kolektif (pemerataan dan pemenuhan kebutuhan dasar) untuk mempertahankan kehidupan muslim secara makro dengan menjaga kekuatan sendi-sendi sosial ekonomi.

Kondisi pandemi COVID-19 yang telah memberikan dampak negatif bagi kondisi sosial ekonomi sebagian masyarakat di Indonesia. Kondisi tersebut bukan tanpa alasan mengingat dampak ekonomi secara serentak telah berlaku di beberapa negara (Fornaro \& Wolf, 2020), termasuk di Indonesia yang memiliki angka kerja 126,51 juta pekerja baik di sektor formal atau informal (Badan Pusat Statistik Republik Indonesia, 2020). Melalui proporsi yang telah dijelaskan sebelumnya, maka terdapat 110,1 juta pekerja muslim yang terdampak pandemi. Di Indonesia, dampak yang paling signifikan terjadi pada konsumsi rumah tangga dan pertumbuhan ekonomi. Kami memastikan bahwa penyebabnya adalah masyarakat cenderung bekerja di rumah (work from home) dan beberapa sektor usaha yang mulai berkurang sehingga turut berdampak pada aspek lainnya seperti produktivitas ketenagakerjaan, penurunan keuntungan, hingga pemutusan hubungan kerja bagi sektor usaha formal yang mengalami kebangkrutan.

Sejak otoritas memberlakukan pembatasan pada kawasan rumah ibadah umat muslim di hampir semua rumah ibadah, ekonomi cenderung melemah di hampir semua sektor dan membuat daya beli masyarakat menurun. Kami memutuskan "kerentanan umat muslim" sebagai kata kunci yang secara kuat merepresentasikan tingginya jumlah umat muslim yang terkena dampak pandemi COVID-19. Dalam kondisi tersebut, maka berbagai dampak negatif akibat memburuknya kondisi ekonomi. Hal tersebut sangat berpotensi muncul di masyarakat, menimbulkan stagnasi, dan kerugian sosial ekonomi hingga 
meningkatkan jumlah masyarakat miskin akibat ketidakstabilan kondisi dan keberadaan wabah yang tidak kunjung berakhir. Beberapa kajian menunjukkan bahwa fenomena dampak sosial ekonomi baik secara makro maupun mikro telah terjadi di Indonesia, yang mana hal tersebut meemberikan dampak signifikan pada rantai pasok usaha dan ekonomi masyarakat. Fenomena tersebut juga turut membuat kondisi sosial masyarakat memburuk. Hal ini mengingat bencana merupakan fenomena yang berimbas pada kerentanan di banyak aspek kehidupan baik secara individu atau kolektif, termasuk dampak sosial (Gil-Rivas \& Kilmer, 2016). Di samping itu, telah terjadi sentimen negatif masyarakat dan publik di dunia maya selama pandemi COVID-19 terhadap pangan dan logistik, yang mana sentimen negatif media sosial, berita digital, dan situs web adalah indikasi adanya gangguan terhadap stabilitas kerentanan sosial (Kryvasheyeu dkk., 2016).

Penurunan ketahanan masyarakat karena pandemi COVID-19 turut berimbas pada respon negatif yang muncul. Sikap tersebut merupakan realita penolakan dan pengabaian anjuran pemerintah hingga tindakan irasional. Hal ini karena pihak otoritas sendiri kurang mampu mengakomodir sikap dan harapan masyarakat dalam mengatasi pelemahan ekonomi masyarakat di saat pandemi masih berlangsung. Kondisi hari ini menunjukkan bahwa sempat terjadi sikap atau tindakan irasional masyarakat secara umum berangkat dari kemampuan pihak otoritas secara menyeluruh seperti panic buying dan panic in debt. Meskipun belum masuk dalam kategori tindakan kriminal, tetapi pada dasanya fenomena tersebut merugikan masyarakat umum ketika membutuhkan di situasi darurat. Panic buying dalam bentuk pembelian berlebih alat kesehatan seperti makanan, masker, dan hand sanitizer. Hal tersebut secara umum mengakibatkan pihak yang lebih membutuhkan seperti dokter, tenaga kesehatan, dan pekerja yang harus berada di luar rumah cenderung kesulitan saat membutuhkan. Dampaknya adalah muncul pihak-pihak yang tidak bertanggungjawab yang kemudian memanfaatkan kelangkaan barang-barang tersebut dengan harga yang tinggi. Fenomena tersebut muncul dari informasi wabah yang membuat masyarakat beranggapan negatif hingga memutuskan berperilaku demikian untuk mengurangi risiko terinfeksi dan menahan diri untuk bepergian ke tempat umum (Jung, Park, Hong, \& Hyun, 2016). Sementara panic in debt, muncul berbentuk tindakan masyarakat yang bernafsu meminjam uang pada lembaga peminjaman, bank, rentenir, dan sebagainya meskipun dikenakan bunga yang tinggi. Tindakan irasional tersebut merupakan naluri kesadaran masyarakat yang muncul akan ancaman krisis pandemi COVID-19 yang menjadikan fluktuasi kondisi ekonomi masyarakat.

\section{“...Tidak akan menimbun barang kecuali dia} seorang pendosa...” (HR Muslim)

“...Barangsiapa menimbun bahan makanan bagi umat muslim maka Tuhan akan menimpakan penyakit lepra dan kebangkrutan..." (HR Ibnu Majah, Ahmad, \& Hakim)

Di Indonesia sendiri, sempat terjadi permintaan makanan pokok yang cenderung melonjak dan terjadi kenaikan harga. Meskipun secara sosiologis upaya tersebut adalah bentuk naluri bertahan hidup, tetapi dalam Islam hal tersebut tidak diperbolehkan selama terjadi masa sulit seperti pandemi. Islam hanya memperbolehkan seseorang memborong suatu barang ketika kondisi ekonomi stabil dan bukan untuk tujuan melakukan tindakan merugikan atau mempersulit masyarakat (Cahyadi, 2012). Dengan kata lain Islam memiliki prinsip yang bertentangan dengan keberadaan umat muslim di Indonesia yang tengah melakukan bentuk aktivitas panic buying dan panic in debt. Alasannya adalah dapat memunculkan ancaman baru seperti naiknya harga-harga, bunga utang yang tinggi, dan rente baru untuk menaikkan harga melebihi rentang harga normal di tengah sulinya situasi ekonomi di Indonesia. Kebijakan otoritas juga mengharamkan adanya berbagai tindakan tersebut melalui penetapan fatwa haram melakukan tindak panic buying kemudian menimbun logistik untuk kembali dijual dengan harga tinggi.

Pandemi COVID-19 secara nyata telah berdampak tidak hanya pada kondisi ekonomi penduduk terdampak di Indonesia, tetapi juga pada kondisi sosial dan psikis. 
Selain masyarakat kehilangan pekerjaan dan penghasilan, mereka juga mengalami depresi selama pandemi. Hingga bulan Juni 2020, pandemi COVID-19 telah membuat lebih dari 3 juta pekerja kehilangan pekerjaannya, yang mana masih terdapat pekerja terdampak lain karena laporan belum secara penuh (Ameidyo Daud Nasution, 2020; Fowler, 2020). Depresi bukan hanya terjadi ketika kehilangan pekerjaan dan menjadi pengangguran baru, tetapi juga adanya stigma akan potensi dampak COVID-19 membuat masyarakat panik dan gelisah (Fowler, 2020). Selain itu, bagi masyarakat yang kehilangan pekerjaan, terdapat perasaan marah, kecewa, tersinggung, bahkan mengganggu kesehatan mental dan masuk dalam kategori masyarakat rentan terhadap dampak sosial dari pandemi yang tidak terkontrol (Fowler, 2020). Konsekuensi dari kondisi tersebut bahwa masyarakat terdampak tidak hanya membutuhkan uang dan strategi ekonomi untuk dapat memulihkan kondisi, tetapi juga motivasi dan perbaikan kondisi sosial dari kerentanan akibat pandemi COVID-19.

Islam pada dasarnya memiliki alternatif solusi di tengah pandemi berupa Konsep Maqasid Asy-Syari'ah dalam bentuk menjaga harta secara kolektif (pemerataan dan pemenuhan kebutuhan dasar). Alternatif ini berangkat dari nilai dan prinsip moderat, keadilan, keseimbangan, serta menspesifikkan antara materi dengan etika. Maqasid Asy-Syari'ah menawarkan konsep kesejahteraan tidak hanya mencakup aspek kesejahteraan ekonomi, tetapi juga kesejahteraan lainnya mencakup sosial dan spiritual dengan basis 4 kerangka utama yakni: pertama, Tauhid sebagai ruh paling mendasar dari keyakinan agama Islam, sebagai bentuk kepasrahan atas keyakinan pada Tuhan; kedua, risalah dari Nabi Muhammad berupa kitab suci sebagai pedoman; ketiga, keyakinan atas adanya pertanggungjawaban kepada Tuhan tentang aktivitas duniawi yang salah satunya adalah kegiatan ekonomi dan materi, dan; keempat, kesejahteraan untuk hidup dan bersosialisasi yang lebih baik (Sadeq \& Ghazali, 2006). Di sisi lain dari perspektif kebijakan, Maqasid Asy-Syari'ah juga diperkuat dengan adanya Fatwa MUI Nomor 23 Tahun 2020 tentang Pemanfaatan Harta Zakat, Infaq, dan
Shadaqah untuk Penanggulangan Wabah Covid-19 dan Dampaknya. Fatwa tersebut mencerminkan adanya keinginan dari pihak otoritas agas masyarakat muslim yang berkecukupan untuk berkontribusi dalam penguatan umat melalui zakat, infaq, dan shadaqah dari harta hasil mata pencaharian yang dimiliki dan tetap berkecukupan meskipun telah terdampak pandemi.

\begin{tabular}{|c|c|c|}
\hline Aspek & $\begin{array}{c}\text { Konsep } \\
\text { Ekonomi } \\
\text { Konvensional }\end{array}$ & $\begin{array}{c}\text { Konsep } \\
\text { Ekonomi } \\
\text { Maqasid Asy- } \\
\text { Syari'ah } \\
\end{array}$ \\
\hline $\begin{array}{l}\text { kesejahte } \\
\text { raan }\end{array}$ & $\begin{array}{l}\text { 1. Pendapatan } \\
\text { dan tingkat } \\
\text { konsumsi; } \\
\text { 2. Jaminan } \\
\text { kesehatan; } \\
\text { 3. Hunian; } \\
\text { 4. Dukungan } \\
\text { finansial; } \\
\text { 5. Pendidikan }\end{array}$ & $\begin{array}{l}\text { Menyelaraska } \\
\text { n antara: } \\
\text { 1. Kebutuhan } \\
\text { materi; } \\
\text { 2. Etika } \\
\text { kehidupan } \\
\text { manusia. }\end{array}$ \\
\hline Prinsip & $\begin{array}{l}\text { Optimasi } \\
\text { kekayaan, } \\
\text { harta fisik, } \\
\text { manusia } \\
\text { sebagai mesin } \\
\text { konsumsi }\end{array}$ & $\begin{array}{l}\text { 'Adl } \\
\text { (keadilan), } \\
\text { Khilaafah } \\
\text { (authority), \& } \\
\text { Ma'ad } \\
\text { (orientasi } \\
\text { hasil), atau; } \\
\text { multiple } \\
\text { ownership, } \\
\text { freedom to } \\
\text { act, \& social } \\
\text { justice }\end{array}$ \\
\hline Nilai & $\begin{array}{l}\text { Hedonism \& } \\
\text { materialism }\end{array}$ & $\begin{array}{l}\text { Social welfare } \\
\& \text { spiritualism }\end{array}$ \\
\hline
\end{tabular}

Tabel 1. Dikotomi Kerangka Konsep Ekonomi Modern dan Maqasid Asy-Syariah

Konsep ekonomi modern yang hanya mengedepankan nilai materi (dengan menggunakan mata uang) pada dasarnya telah mengesampingkan atau hanya sedikit mempertimbangkan keberadaan moral, spiritual, dan etika kemanusiaan. Beberapa variabel dalam konsep ekonomi modern sangat erat hubungannya dengan konsepsi materialis hedonis dang sangat kontroversial bagi aspek kesejahteraan sosial, yang mana hanya mengunggulkan optimasi kekayaan, kenikmatan fisik, dan kepuasan pribadi. Sedangkan dalam konsepsi Islam, lebih tepatnya Maqasid Asy-Syariah, tujuan 
ekonomi dan aktivitasnya berorientasi pada kebermanfaatan umat. Tingkat konsumsi yang menjadi tujuan dalam konsep ekonomi modern, berbeda dengan cara pandang konsumsi dalam Maqasid Asy-Syariah yang menjadikan konsumsi sebagai konsekuensi hidup. Ketika konsumsi menjadi tujuan, maka manusia sangat berpotensi untuk menjadi rakus dan tidak mempedulikan manusia lainnya sehingga terjadi over konsumsi. Berbeda ketika kita meletakkan konsumsi dalam perspektif Maqasid AsySyariah, yang kemudian menjadikan manusia mendasarkan konsumsi berdasarkan kebutuhan jiwa, fisik, dan sumber daya yang dimiliki secara holistik dan kontekstual. Pandangan Maqasid Asy-Syariah mengorientasikan ekonomi pada 2 hal: pertama, kesejahtraan holistic dan seimbang mencakup dimensi materi dan spiritual serta individu dan sosial, dan; kedua, kesejahteraan di dunia akhirat, yang mana umat muslim meyakini adanya pertanggungjawaban dari aktivitas kehidupan setelah kematian di dunia termasuk dalam kegiatan ekonomi.

Konsep Maqasid Asy-Syari'ah berangkat dari adanya konsep ekonomi hari ini yang hanya mengedepankan aspek-aspek kesejahteraan materiil (Grusky \& Kanbur, 2006). Aspek ekonomi modern menganggap bahwa aspek materiil adalah indikator yang tepat, yang kemudian menjabarkan dalam bentuk pendapatan dan tingkat konsumsi, jaminan kesehatan, hunian, dukungan finansial, pendidikan, dan bidang kesejahteraan sosial lain (Sherraden \& Gilbert, 2016). Sedangkan, berbeda dengan konsep ekonomi modern yang hanya mengedepankan aspek-aspek materiil, Maqasid Asy-Syari'ah menjelaskan bahwa dalam prosesnya, terdapat jaminan terhadap terwujudnya keteraturan, keselamatan, kedamaian, dan kesejahteraan melalui keseimbangan dari masing-masing aspek. Hal ini sejalan dengan adanya konsep keberhasilan ekonomi Islam masa depan yang menekankan adanya keselarasan antara kebutuhan materi dan etika, serta Maqasid Asy-Syari'ah memberikan kontribusi langsung terhadap kesejahteraan manusia (Chapra, 2016).

\section{Kesimpulan}

Pandemi COVID-19 hari ini masih belum usai dan menyisakan beberapa dampak berupa: pertama, kebiasaan beribadah umat muslim yang cenderung mengalami transisi dalam jumlah yang lebih kecil; kedua, kebijakan yang dirumuskan merupakan bentuk penyesuaian antara pengalaman Islam dengan kondisi kontekstual hari ini, dan; ketiga, terdapat $87 \%$ umat muslim yang mengalami kerentanan ekonomi akibat adanya pandemi COVID-19. Dalam hal ini, umat muslim tidak bisa hanya berpikir secara jabariyah atau pasrah, tetapi juga diwajibkan untuk terus berusaha di tengah pandemi COVID-19 baik dalam konteks keyakinan atau kemanusiaan. Dalam konteks keyakinan, kepasrahan umat muslim kepada Tuhan merupakan bentuk keimanan di tengah era modern dan ujian. Upaya yang tidak kalah penting yakni konteks kemanusiaan, bahwa umat muslim harus terus mengusahakan diri untuk saling bertanggungjawab dalam konteks sosial ekonomi, bukan hanya untuk sesama muslim di Indonesia, tetapi juga untuk seluruh masyarakat dalam mengatasi kerentanan karena pandemi.

\section{Daftar Pustaka}

Aji, A. M., \& Habibaty, D. M. (2020). Fatwa Majelis Ulama Indonesia Tentang Penyelenggaraan Ibadah Dalam Situasi Terjadi Wabah Covid-19 Sebagai Langkah Antisipatif dan Proaktif Persebaran Virus Corona Di Indonesia. SALAM: Jurnal Sosial dan Budaya Syar-i, 7(8), 673-686. https://doi.org/10.15408/sjsbs.v7i8.1 7059

Al-Osail, A. M., \& Al-Wazzah, M. J. (2017). The History and Epidemiology of Middle East Respiratory Syndrome Corona Virus. Multidisciplinary Respiratory Medicine, 12(1), 20. https://doi.org/10.1186/s40248-0170101-8

Ameidyo Daud Nasution. (2020, Juni 12). Menaker Sebut 3 Juta Pekerja Dirumahkan dan Kena PHK Imbas Corona. Diambil 27 Desember 2021, dari

https://katadata.co.id/ameidyonasutio n/berita/5ee33f108fef5/menaker- 
sebut-3-juta-pekerja-dirumahkandan-kena-phk-imbas-corona

Anderson, J. E. (2005). Public Policymaking: An Introduction 6th (sixth) edition. United States: Example Product Manufacturer.

Arrow, K., \& Priebsch, M. (2014). Bliss, Catastrophe, and Rational Policy. Environmental and Resource Economics, 58, 491-509. https://doi.org/10.1007/s10640-0149788-6

Bentzen, J. S. (2021). In Crisis, we Pray: Religiosity and the COVID-19 Pandemic. Journal of Economic Behavior \& Organization, 192, 541583.

https://doi.org/10.1016/j.jebo.2021.1 0.014

Birkland, T. A. (2010). An Introduction to the Policy Process: Theories, Concepts, and Models of Public Policy Making, 3rd (3rd edition). Armonk, NY: M.E. Sharpe.

Biswas, K., Khaleque, A., \& Sen, P. (2020). Covid-19 Spread: Reproduction of Data and Prediction Using a SIR Model on Euclidean Network. arXiv:2003.07063 [cond-mat, physics:physics, q-bio]. Diambil dari http://arxiv.org/abs/2003.07063

Cahyadi, I. F. (2012). The Science of Death: Ikhlas Menyambut Maut untuk Kedamaian di Akhir Hidup. Jakarta: Qultum Media.

Chapra, M. U. (2016). The Future of Economics: An Islamic Perspective. Leicester: Kube Publishing Ltd.

Creswell, J. W., \& Creswell, J. D. (2018). Research Design: Qualitative, Quantitative, and Mixed Methods Approaches. Thousand Oaks: SAGE Publications.

Dror, Y. (1964). Muddling Through"Science" or Inertia? Public Administration Review, 24(3), 153157. https://doi.org/10.2307/973640

Durkheim, É. (2013). Les formes élémentaires de la vie religieuse: Le système totémique en Australie (PUF edition). Paris: PUF.

Ferris, T. (2011). Science of Liberty: Democracy, Reason, and the Laws of Nature (Reprint edition). New York: Harper Perennial.
Fornaro, L., \& Wolf, M. (2020, April 2). Covid-19 Coronavirus and Macroeconomic Policy. Diambil 27 Desember 2021, dari Barcelona School of Economics website: https://bse.eu/research/workingpapers/covid-19-coronavirus-andmacroeconomic-policy

Fowler, D. (2020, April 24). Virus Corona: Efek Psikologis Setelah Kehilangan Pekerjaan Selama Pandemi Covid19. BBC News Indonesia. Diambil dari

https://www.bbc.com/indonesia/vertcap-52408458

Freud, S., \& Gay, P. (1989). The Future of an Illusion (The Standard edition; J. Strachey, Ed.). New York: W. W. Norton \& Company.

Gil-Rivas, V., \& Kilmer, R. P. (2016). Building Community Capacity and Fostering Disaster Resilience. Journal of Clinical Psychology, 72(12), 1318-1332. https://doi.org/10.1002/jclp.22281

Grusky, D. B., \& Kanbur, R. (2006). Poverty and Inequality. Stanford: Stanford University Press.

Iannaccone, L. R. (1998). Introduction to the Economics of Religion. Journal of Economic Literature, 36(3), 14651495.

Ibrahim, A. (2020, Juni 4). Praying in Time of COVID-19: How World's Largest Mosques Adapted. Diambil 27 Desember 2021, dari https://www.aljazeera.com/news/202 0/4/6/praying-in-time-of-covid-19how-worlds-largest-mosques-adapted

Iqbal, Z., \& Mirakhor, A. (2010). An Islamic Perspective on Economic Development. Dalam W. El-Ansary \& D. K. Linnan (Ed.), Muslim and Christian Understanding: Theory and Application of "A Common Word" (hlm. 221-233). New York: Palgrave Macmillan US. https://doi.org/10.1057/97802301144 01_17

Jung, H., Park, M., Hong, K., \& Hyun, E. (2016). The Impact of an Epidemic Outbreak on Consumer Expenditures:An Empirical Assessment for MERS Korea. 
Sustainability, $\quad 8(5), \quad 454$. https://doi.org/10.3390/su8050454

KH. (2020, Oktober 3). Wawancara.

Kryvasheyeu, Y., Chen, H., Obradovich, N., Moro, E., Van Hentenryck, P., Fowler, J., \& Cebrian, M. (2016). Rapid Assessment of Disaster Damage Using Social Media Activity. Science Advances, 2(3), e1500779.

https://doi.org/10.1126/sciadv.15007 79

Li, Q., Feng, W., \& Quan, Y.-H. (2020). Trend and Forecasting of the COVID-19 Outbreak in China. Journal of Infection, 80(4), 469-496. https://doi.org/10.1016/j.jinf.2020.02 .014

Li, R., Qiao, S., \& Zhang, G. (2020). Analysis of Angiotensin-Converting Enzyme 2 (ACE2) From Different Species Sheds Some Light on CrossSpecies Receptor Usage of a Novel Coronavirus 2019-nCoV. The Journal of Infection, 80(4), 469-496. https://doi.org/10.1016/j.jinf.2020.02 .013

Martin, I. W. R., \& Pindyck, R. S. (2015). Averting Catastrophes: The Strange Economics of Scylla and Charybdis. American Economic Review, 105(10), 2947-2985. https://doi.org/10.1257/aer.20140806

Martin, I. W. R., \& Pindyck, R. S. (2021). Welfare Costs of Catastrophes: Lost Consumption and Lost Lives. Economic Journal, 131(634), 946969.

Marx, K. (1970). Critique of Hegel's "Philosophy of Right." Cambridge University Press.

Mugiyono, M. (2013). Perkembangan Pemikiran dan Peradaban Islam Dalam Perspektif Sejarah. Jurnal Ilmu Agama UIN Raden Fatah, 14(1), 1-20.

Norris, P., \& Inglehart, R. (2011). Sacred and Secular: Religion and Politics Worldwide (2nd edition). Cambridge: Cambridge University Press.

Qi, Y., Du, C. D., Liu, T., Zhao, X., \& Dong, C. (2020). Experts' Conservative Judgment and Containment of COVID-19 in Early Outbreak. $J$. Chinese Gov., 140-159.
RA. (2020, Oktober 3). Wawancara.

Remuzzi, A., \& Remuzzi, G. (2020). COVID-19 and Italy: What next? The Lancet, 395(10231), 1225-1228. https://doi.org/10.1016/S01406736(20)30627-9

Rheinberger, C. M., \& Treich, N. (2017). Attitudes Toward Catastrophe. Environmental and Resource Economics, 67(3), 609-636. https://doi.org/10.1007/s10640-0160033-3

RR. (2020, Oktober 3). Wawancara.

Sadeq, A. M. (1990). Economic Development in Islam. Malaysia: Pelanduk Publications.

Sadeq, A. M., \& Ghazali, A. (2006). Readings in Islamic Economic Thought. Kuala Lumpur: Publication Department, Islamic Foundation Bangladesh.

Salleh, M. S. (2017). Contemporary Vision of Poverty and Islamic Strategy for Poverty Alleviation. SAGE, 7(2), 2158244017697153. https://doi.org/10.1177/21582440176 97153

Sherraden, M., \& Gilbert, N. (2016). Assets and the Poor: New American Welfare Policy. New York: Routledge.

Stark, R., \& Finke, R. (2000). Acts of Faith: Explaining the Human Side of Religion. USA: University of California Press.

Vankadari, N., \& Wilce, J. A. (2020). Emerging WuHan (COVID-19) Coronavirus: Glycan Shield and Structure Prediction of Spike Glycoprotein and its Interaction with Human CD26. Emerging Microbes \& Infections, 9(1), 601-604. https://doi.org/10.1080/22221751.20 20.1739565

Weber, M. (2010). The Protestant Ethic and the Spirit of Capitalism (Revised edition; S. Kalberg, Penerj.). New York: Oxford University Press.

Whitworth, J. (2020). COVID-19: A Fast Evolving Pandemic. Transactions of the Royal Society of Tropical Medicine and Hygiene, 114(4), 241248. https://doi.org/10.1093/trstmh/traa02 5 